\title{
Occurrence of Cholelithiasis and Cholecystitis in Amyotrophic Lateral Sclerosis Patients with Long-Term Tracheostomy Invasive Ventilation
}

\author{
Eiji Kitamura and Mieko Ogino
}

\begin{abstract}
Objective We clarified the prevalence of cholelithiasis/cholecystitis in long-term tracheostomy invasive ventilation (TIV) patients in our hospital.

Methods We investigated the occurrence of cholelithiasis/cholecystitis in twenty-seven TIV patients over the past eight years.

Results There were ten patients with cholelithiasis/cholecystitis. The underlying disease was amyotrophic lateral sclerosis (ALS), except for 1 patient. Mean age was $56.2 \pm 4.7$ years and the average period to the attack of cholelithiasis/cholecystitis from TIV was $57.6 \pm 15.1$ months. Two patients of acute cholecystitis had acalculous cholecystitis. Five of the ten patients developed a severe state of cholecystitis and needed aggressive therapy.

Conclusion The prevalence of gallstones, symptom prevalence of asymptomatic cholelithiasis, the percentage of acalculous cholecystitis of acute cholecystitis in TIV patients was higher than in the general population. Therefore, it may be possible that TIV is a risk for cholelithiasis/cholecystitis. Some of the ALS patients with long-term TIV develop severe cholelithiasis/cholecystitis, and those facts should be considered in our daily clinical practice.
\end{abstract}

Key words: amyotrophic lateral sclerosis, tracheostomy invasive ventilation, cholelithiasis, cholecystitis

(Intern Med 50: 2291-2295, 2011)

(DOI: 10.2169/internalmedicine.50.5663)

\section{Introduction}

With recent advances in medicine, the number of neuromuscular disease patients who can live long with tracheostomy invasive ventilation (TIV) has been increasing. Clinicians have to give sufficient consideration when treating patients with TIV to maintain a high quality of life. Prevention of complication is therefore a very important point in daily clinical practice.

For the last few years, we experienced cholelithiasis/ cholecystitis in long-term TIV patients (mainly amyotrophic lateral sclerosis: ALS) in our hospital in succession. There were recurrence cases, some of which needed operation. One case became severe and died of sepsis. As far as we know, based on a literature search, there is little research on cholelithiasis/cholecystitis in long-term TIV patients. It is important for ALS patients who want to live with long-term ventilator support to discover cholelithiasis/cholecystitis in an early stage to receive urgent care. In this retrospective study, we report the occurrence of cholelithiasis/cholecystitis in TIV patients for the past seven years.

\section{Materials and Methods}

\section{Subjects}

Twenty-seven patients, with TIV between April 2002 and March 2010 were retrospectively included in this study (men 15 , women 12 , mean age $56.2 \pm 4.7$ years) (detailed information in Table 1). Eighteen patients had ALS, four patients had muscular dystrophy, two patients had myotubular 
Table 1. Comparison of Ventilated Patients and Bedridden Patients

\begin{tabular}{ccccccc}
\hline & $\begin{array}{c}\text { Number } \\
\text { of cases }\end{array}$ M:F Mean age $\begin{array}{c}\text { Prevalence of } \\
\text { gallstone (\%) }\end{array}$ & $\begin{array}{c}\text { Prevalence of } \\
\text { cholelithiasis } \\
\text { and } \\
\text { cholecystitis } \\
(\%)\end{array}$ & $\begin{array}{c}\text { The percentage of } \\
\text { acalculous } \\
\text { cholecystitis in } \\
\text { acute cholecystitis } \\
(\%)\end{array}$ \\
\hline $\begin{array}{c}\text { Long-term } \\
\text { TIV } \\
\text { patients }\end{array}$ & 27 & $15: 12$ & 56.2 & $29.6(8 / 27)$ & $37.0(10 / 27)^{*}$ & $25.0(2 / 8)$ \\
\hline $\begin{array}{c}\text { Long-term } \\
\text { bedridden } \\
\text { patients }\end{array}$ & 29 & $20: 9$ & 73.7 & $6.9(2 / 29)$ & $6.9(2 / 29)$ & 0 \\
\hline
\end{tabular}

myopathy, and the others had either progressive external ophthalmoplegia, myasthenia gravis, or Pompe disease.

Since there is a possibility that long-term bedridden is a risk for cholelithiasis/cholecystitis, twenty-nine long-term bedridden patients who were not on a ventilator were examined as the comparative controlled patients (mean age is $73.7 \pm 1.6$ years) (Table 1). In the control group, fifteen patients had Parkinson's disease, thirteen patients had Parkinson's syndrome, and one patient had anoxic brain. In both groups, all cases used a gastrostomy tube. For an observational report of twenty-seven cases using data obtained during the regular management of the disease and care without specific investigations performed for a research purpose, approval from our hospital ethics committee was not required.

\section{Diagnosis of cholelithiasis/cholecystitis}

We used the "Diagnostic criteria and severity assessment of acute cholecystitis: Tokyo Guidelines (1)" to diagnose cholelithiasis/cholecystitis. We checked the local signs of inflammation (Murphy's sign and a mass/pain/tenderness in the right upper quadrant), systemic signs of inflammation [fever, elevated C-reactive protein (CRP) level, and elevated white blood cell count), and imaging findings (ultrasonography, magnetic resonance imaging (MRI), and computed tomography (CT)]. We checked age, sex, hypercholesteremia and the number of daily calories to investigate the risks of cholelithiasis.

\section{Statistical analyses}

Statistical difference was investigated by chi-square test, and under certain conditions, Yates' correction was performed. All statistical analyses were performed using SPSS (IBM, Tokyo, Japan).

\section{Results}

Ten of twenty-seven long-term TIV patients displayed cholelithiasis/cholecystitis $(37.0 \%)$. In contrast, there was no patient with cholelithiasis/cholecystitis and only two patients with asymptomatic cholelithiasis among the comparative controlled patients $(6.9 \%)$ which is close to the prevalence in the general population in Japan (2). The prevalence of cholelithiasis/cholecystitis with long-term TIV patients is significantly higher than the comparative controlled patients $(\mathrm{p}=0.015)$.

Eight of ten long-term TIV patients with cholelithiasis/ cholecystitis had gallstone (prevalence of gallstone is 29.6\%). Out of those eight patients, six patients with gallstone developed acute cholecystitis (the rate of change from asymptomatic to symptomatic cholelithiasis is $75.0 \%$ ), and other two patients developed acalculous cholecystitis

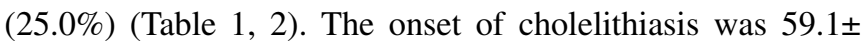
14.6 months after receiving TIV. In general, women are susceptible to cholelithiasis/cholecystitis (3). However, in this study eight of fifteen men with long-term TIV displayed cholelithiasis/cholecystitis patients $(53.3 \%)$, and two of twelve women $(16.7 \%)$ (Table 2). As a result, men were more likely to display cholelithiasis/cholecystitis in this series.

Nine of ten long-term TIV patients with cholelithiasis/ cholecystitis were ALS patients. Therefore, we further examined those long-term TIV ALS patients (18 cases) in detail (Table 3). Seven of nine ALS patients developed acute cholecystitis. There was no significant difference in age, sex, hypercholesteremia, body-mass index (BMI), and the number of daily calories and TIV years, when comparing cholelithiasis/cholecystitis positive group to negative group. Both groups were male-dominated, no hypercholesteremia, and low BMI and daily calories. The risk factors of cholelithiasis/cholecystitis in long-term TIV ALS patients were different from the general risks of cholelithiasis and/or cholecystitis except for the age.

For prognosis of seven acute cholecystitis patients, one case died from septic shock as a result of acute cholecystitis (Case 1). Four cases underwent percutaneous teanshepatic gallbladder drainage (PTGBD) for acute cholecystitis: two of them underwent laparoscopic cholecystectomy later due to the relapse of cholecystitis (Case 2). And the other two cases were improved by antibiotics and prevented development of cholecystitis by ursodeoxycholic acid (Case 3). Thus, half of the patients with acute cholecystitis developed severe symptoms and needed aggressive medical treatment. Some cases are presented as follows.

Case 1: A 52-year-old man with ALS who had TIV since 
Table 2. Summary of 10 Tracheostomy Invasive Ventilation Cases of Cholelithiasis And/or Cholecystitis

\begin{tabular}{|c|c|c|c|c|c|c|c|c|c|c|c|c|c|c|}
\hline Case & Sex & $\begin{array}{c}\text { Age of } \\
\text { cholelithiasis, } \\
\text { cholecystitis onset }\end{array}$ & $\begin{array}{c}\text { Underlying } \\
\text { disease }\end{array}$ & First symptom & Laboratory data & $\begin{array}{l}\text { TIV duration } \\
\text { (months) }\end{array}$ & $\begin{array}{c}\text { Abdominal } \\
\text { ultrasonography }\end{array}$ & $\begin{array}{l}\text { Abdominal } \\
\text { CT }\end{array}$ & Diagnosis & Treatment & Prognosis & $\begin{array}{l}\text { Tcho/TG } \\
(\mathrm{mg} / \mathrm{dL})\end{array}$ & BMI & $\begin{array}{c}\text { The } \\
\text { number of } \\
\text { daily } \\
\text { calories } \\
\text { (kcal) } \\
\end{array}$ \\
\hline 1 & $\mathrm{M}$ & 52 & ALS & $\begin{array}{l}\text { fever, } \\
\text { abdominal } \\
\text { pains }\end{array}$ & $\begin{array}{c}\mathrm{WBC} 8,500 / \mathrm{uL}, \\
\text { CRP20.8mg/dL, } \\
\text { AST104IU/L, } \\
\text { ALT165IU/L, } \\
\text { ALP1185IU/L }\end{array}$ & 72 & $\begin{array}{c}\text { enlarged } \\
\text { gallbladder, debris } \\
\text { echo, thickened } \\
\text { gallbladder wall }\end{array}$ & unchecked & $\begin{array}{l}\text { acalculous } \\
\text { cholecystitis }\end{array}$ & intensive care & dead & $213 / 171$ & 16 & 1250 \\
\hline 2 & $\mathrm{M}$ & 75 & ALS & fever & $\begin{array}{c}\mathrm{WBC} 18,300 / \mathrm{uL}, \\
\mathrm{CRP} 10.1 \mathrm{mg} / \mathrm{dL}, \\
\text { AST312IU/L, } \\
\text { ALT292IU/L, } \\
\mathrm{Y}^{-\mathrm{GTP}} 662 \mathrm{IU} / \mathrm{L} \\
\text { ALP912IU/L }\end{array}$ & 99 & $\begin{array}{l}\text { debris echo, } \\
\text { gallstone }\end{array}$ & gallstone & cholecystitis & $\begin{array}{c}\text { antibiotic, } \\
\text { PTGBD, } \\
\text { laparoscopic } \\
\text { cholecystectomy }\end{array}$ & improved & $156 / 234$ & 18 & 1000 \\
\hline 3 & $\mathrm{M}$ & 57 & ALS & fever & $\begin{array}{c}\text { WBC5,800/uL, } \\
\text { CRP5.9mg/dL, } \\
\text { AST63IU/L, } \\
\text { ALT98IU/L, } \\
\text { Y-GTP218IU/L, } \\
\text { ALP1241IU/L } \\
\end{array}$ & 1 & $\begin{array}{c}\text { thickened } \\
\text { gallbladder wall, } \\
\text { debris echo, } \\
\text { pericholecystic fluid } \\
\text { collection } \\
\end{array}$ & $\begin{array}{c}\text { enlarged } \\
\text { gallbladder, } \\
\text { debris, } \\
\text { thickened } \\
\text { gallbladder } \\
\text { wall } \\
\end{array}$ & $\begin{array}{l}\text { acalculous } \\
\text { cholecystitis }\end{array}$ & antibiotic & improved & $141 / 91$ & 16 & 1200 \\
\hline 4 & $\mathrm{M}$ & 55 & ALS & $\begin{array}{c}\text { fever, } \\
\text { abdominal } \\
\text { pains }\end{array}$ & 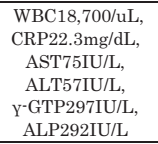 & 157 & debris echo & $\begin{array}{c}\text { enlarged } \\
\text { gallbladder, } \\
\text { gallstone, } \\
\text { thickened } \\
\text { gallbladder } \\
\text { wall } \\
\end{array}$ & cholecystitis & antibiotic, PTGBD & improved & $191 / 134$ & 16 & 1200 \\
\hline 5 & $\mathrm{M}$ & 54 & ALS & $\begin{array}{c}\text { fever, } \\
\text { abdominal } \\
\text { pains }\end{array}$ & 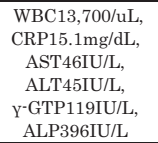 & 56 & $\begin{array}{c}\text { enlarged } \\
\text { gallbladder, } \\
\text { gallstone, thickened } \\
\text { gallbladder wall, } \\
\text { pericholecystic fluid } \\
\text { collection }\end{array}$ & $\begin{array}{c}\text { enlarged } \\
\text { gallbladder, } \\
\text { gallstone, } \\
\text { thickened } \\
\text { gallbladder } \\
\text { wall }\end{array}$ & cholecystitis & $\begin{array}{c}\text { antibiotic, } \\
\text { PTGBD, } \\
\text { laparoscopic } \\
\text { cholecystectomy }\end{array}$ & improved & $115 / 44$ & 16 & 1200 \\
\hline 6 & $\mathrm{M}$ & 55 & ALS & fever & $\begin{array}{c}\text { WBC11,000/uL, } \\
\text { CRP3.7mg/Ll, } \\
\text { AST32IU/L, } \\
\text { ALT30IU/L, } \\
\text { Y GTP84IU/L, }^{-G} \text { ALP422IU/L } \\
\end{array}$ & 33 & $\begin{array}{c}\text { enlarged } \\
\text { gallbladder, debris } \\
\text { echo }\end{array}$ & gallstone & cholecystitis & antibiotic & improved & $195 / 233$ & 20 & 1000 \\
\hline 7 & $\mathrm{M}$ & 62 & ALS & $\begin{array}{l}\text { asymptomatic, } \\
\text { elevated } \\
\text { hepatobiliary } \\
\text { enzymes }\end{array}$ & 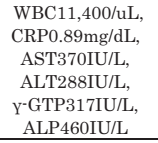 & 80 & gallstone & unchecked & cholecystitis & antibiotic & improved & $131 / 134$ & 18 & 1200 \\
\hline 8 & $\mathrm{~F}$ & 61 & ALS & asymptomatic & $\begin{array}{c}\text { WBC6,100/uL, } \\
\text { CRP0.1mg/dL, } \\
\text { AST17IU/L, } \\
\text { ALT11IU/L, } \\
\text { Y-GTP19IU/L, } \\
\text { ALP183IU/L } \\
\end{array}$ & 2 & unchecked & gallstone & cholelithiasis & observation & improved & $221 / 75$ & 22 & 1125 \\
\hline 9 & $\mathrm{M}$ & 71 & ALS & $\begin{array}{l}\text { abdominal } \\
\text { pains }\end{array}$ & 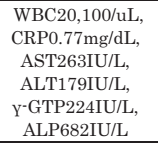 & 21 & $\begin{array}{l}\text { enlarged } \\
\text { gallbladder }\end{array}$ & $\begin{array}{l}\text { enlarged } \\
\text { gallbladder, } \\
\text { gallstone }\end{array}$ & cholecystitis & antibiotic, PTGBD & improved & $165 / 35$ & 14 & 1200 \\
\hline 10 & $\mathrm{~F}$ & 20 & FCMD & $\begin{array}{l}\text { asymptomatic, } \\
\text { elevated } \\
\text { hepatobiliary } \\
\text { enzymes }\end{array}$ & $\begin{array}{c}\text { WBC5,300/uL, } \\
\text { CRP0.2mg/dL, } \\
\text { AST35IU/L, } \\
\text { ALT55IU/L, } \\
\text { Y-GTP52IU/L, } \\
\text { ALP236IU/L }\end{array}$ & 55 & unchecked & gallstone & cholelithiasis & observation & improved & $243 / 374$ & unchecked & 1200 \\
\hline
\end{tabular}

1998. In May 2004, he had a fever of $38^{\circ} \mathrm{C}$ and reduced urine output. His state was improved by antibiotics but had a fever again. He was hospitalized immediately because of abdominal pains, impaired consciousness and blood pressure reduction. Disseminated intravascular coagulation and liver dysfunction were detected by the blood test. Debris echo, enlarged gallbladder and thickened gallbladder wall were detected by abdominal ultrasound. He was diagnosed as septic shock with acute cholecystitis. His general status was severe and he died on the following day.

Case 2: A 75-year-old man with ALS who had TIV since 1997. In July 2005, he was admitted to our hospital because of a fever of $39^{\circ} \mathrm{C}$, elevated CRP and transaminase. Debris echo and gallstone were detected by abdominal ultrasound. He was diagnosed as acute cholecystitis with gallstone. His condition was improved with antibiotics therapy and he was discharged from the hospital. However, about one week later, he was admitted again due to the relapse of cholecysti- tis. Since the effect of inhalation anesthesia on ALS was unknown, he chose to undergo PTGBD and was discharged with it. In March 2003, he was admitted again due to the relapse of cholecystitis. In May, he underwent laparoscopic cholecystectomy, and after that he has being achieving relapse-free home care.

Case 3: A 57-year-old man with ALS who initially developed dysarthria in February 2004. In October 2005, he displayed respiratory muscle failure and was put on a mechanical ventilator. In addition, he was suffering from aspiration pneumonia and was fed by a gastrostomy tube. In lateOctober, he developed a fever and elevated transaminase was detected by biochemical examination of blood. Debris echo, thickened gallbladder wall and pericholecystic fluid collection were detected by abdominal ultrasound. He was diagnosed as acute acalculous cholecystitis. Since acute acalculous cholecystitis was discovered early, his state was improved with treatment of antibiotics. 
Table 3. Comparisons of Cholelithiasis/cholecystitis Positive and Negative ALS Patients with TIV

\begin{tabular}{|c|c|c|c|c|c|c|c|c|}
\hline & & $\begin{array}{l}\text { Number } \\
\text { of cases }\end{array}$ & Mean age & $\begin{array}{l}\text { Sex } \\
M: F\end{array}$ & $\begin{array}{l}\text { TIV duration } \\
\text { (months) }\end{array}$ & Hypercholesteremia & Mean BMI & $\begin{array}{c}\text { The number } \\
\text { of daily } \\
\text { calories } \\
\text { (kcal) }\end{array}$ \\
\hline \multirow{2}{*}{$\begin{array}{l}\text { Cholelithiasis } \\
\text { /cholecystitis }\end{array}$} & + & 9 & 60.2 & $8: 1$ & 57.9 & - & 15.4 & 1153 \\
\hline & - & 9 & 57.3 & $6: 3$ & 67.3 & - & 17.2 & 1100 \\
\hline
\end{tabular}

ALS; amyotrophic lateral sclerosis, BMI; body-mass index

TIV; tracheostomy invasive ventilation

\section{Discussion}

The number of cases of cholelithiasis has increased to over 10 million in 1993 (Public Welfare Index in Japan; 1993). Of the natural history of cholelithiasis, serious symptoms or complications (acute cholecystitis, acute cholangitis, clinical jaundice, and pancreatitis) were observed in $1-2 \%$ of asymptomatic patients and in $1-3 \%$ of patients with mild symptoms per year (3). Cholecystolithiasis accounts for 90$95 \%$ of all causes of acute cholecystitis, while acalculous cholecystitis accounts for the remaining 5-10\% (3). It has been classically known that the patients with cholelithiasis have factors such as " $4 \mathrm{~F}$ " and " $5 \mathrm{~F}$ " (female, fat, fertile, fair, forty). In "Tokyo Guidelines" published as the international guidelines in 2007, it is pointed out that no study has examined the association of factors other than obesity and age with the risk of onset of acute cholecystitis $(3,4)$.

The prevalence of gallstone among long-term TIV patients was $29.6 \%$. The rate of change from asymptomatic to symptomatic cholelithiasis (include acute cholecystitis) was $75 \%$. Both rates are higher than those of the general population in Japan [2.6-18.9\% (2), 15.5-33.2\% (5), respectively]. For the long-term bedridden patients as comparative controlled patients, the prevalence of gallstone was in the same range of general population in Japan. The prevalence of cholelithiasis/cholecystitis among long-term TIV patients was significantly higher than the long-term bedridden patients (Table $1,{ }^{*} \mathrm{p}<0.05$ ).

Mean age of long-term TIV patients with cholelithiasis/ cholecystitis was in the same range of general population in Japan. There were more men than women who displayed cholelithiasis/cholecystitis. And mean BMI was lower than 22. The risks of cholelithiasis/cholecystitis with long-term TIV patients are less likely to be related to the risks such as $4 \mathrm{~F}$ and $5 \mathrm{~F}$. It was pointed out that retraction of gallbladder was a sluggish pace by bedridden state and then the formation of gallstone was promoted (6) and that tube feeding is a risk factor of acute cholecystitis (7). However, the prevalence of gallstone with long-term bedridden patients in this control group was in the same range of the general population in Japan. Our data suggest that long-term bedridden states are not necessarily the risk of gallstone. Also almost all long-term TIV patients and long-term bedridden patients were fed by a gastrostomy tube in this study, therefore tube feeding is also not necessarily a risk for a gallstone.
Acalculous cholecystitis which defined as acute inflammation of the gallbladder in the absence of stones is accounts for $2.0-15.0 \%$ of acute cholecystitis and is likely to occur in patients with serious disease, and has a poor prognosis (8). The prevalence of acute acalculous cholecystitis among acute cholecystitis with long-term TIV patients was high $(25.0 \%)$. Although, these patients were not in serious condition before the onset of acute acalculous cholecystitis, one patient died within 24 hours (Case 1). Therefore, it is important to take into consideration the possibility of acute acalculous cholecystitis with long-term TIV patients.

In this study ALS patients with long-term TIV showed more chance to develop cholelithiasis/cholecystitis. There were not any general risks except for their age, therefore there may be other reasons to explain the mechanism of cholelithiasis/cholecystitis in ALS patients. It is possible the long-term TIV itself is a risk for cholelithiasis/cholecystitis. However, it is difficult to find an appropriate age-matched control group to study and we could not verify the reports about the long-term TIV with cholelithiasis/cholecystitis as far as we know from our literature search. There are several reports which suggest that ALS patients have autonomic nerve system impairment such as constipation or hyperfunction of the adrenergic sympathetic nervous system $(9,10)$. Intestinal hypoperistalsis may cause poor contractility with biliary stasis and sludge formation. Also sympathetic activation can contribute significantly to splanchnic hypoperfusion (11) and may lead to poor contractility with biliary stasis, sludge and gallstone formation.

In the present study, half of the long-term TIV ALS patients with cholelithiasis/cholecystitis needed aggressive medical treatment. One of the reasons why cholelithiasis/ cholecystitis became severe may be that it is difficult for the TIV ALS patients to communicate with words about abdominal symptoms despite lucidity because of progression of ALS, therefore it may be difficult to diagnosis early. In addition, the elevation of aspirate aminotransferase and alanine aminotransferase do not occur at the early stage of acute cholecystitis. Therefore, it is recommended that CRP should be measured and abdominal ultrasonography should be performed in patients who have possibilities of acute cholecystitis (1). We consider that these easy to use examinations are useful in TIV patients who have difficulty undergoing $\mathrm{CT}$ and MRI.

It is recommended that TIV may be considered to preserve QOL in patients with ALS who want long-term venti- 
lator support in ALS guidelines of American Academy of Neurology in 2009 (12). It is important for ALS patients who want to live with long-term ventilator support to discover cholelithiasis/cholecystitis in early stage to receive rapid cure.

In conclusion, the prevalence of cholelithiasis/cholecystitis in long-term TIV patients (especially ALS patients) is high and cholelithiasis/cholecystitis may become severe. It is important that clinicians recognize the possibility of cholelithiasis/cholecystitis in long-term TIV ALS patients, and perform risk assessment (such as ultrasonography) even if there is no symptom. This leads to early detection and treatment of cholelithiasis/cholecystitis. Likewise, when long-term TIV ALS patients show symptoms of infection, clinicians are encouraged to include cholelithiasis/cholecystitis as one of the possible cause of the infection.

The authors state that they have no Conflict of Interest (COI).

\section{Acknowledgement}

We thank Mitsuhiro Kida, M.D. (Department of Gastroenterology Kitasato University School of Medicine, Japan) for help in the diagnosis of cholelithiasis/cholecystitis.

Funding: This work was supported in part by Health and Labour Sciences Research Grants for research on intractable diseases from Ministry of Health, Labour and Welfare of Japan.

\section{References}

1. Hirota M, Takada T, Kawarada Y, et al. Diagnostic criteria and severity assessment of acute cholecystitis: Tokyo Guidelines. J He- patobiliary Pancreat Surg 14: 78-82, 2007.

2. Saito K, Kanno S, Omori H. Silent gallstone and its treatment. Gekachiryou 64: 813-823, 1991 (in Japanese).

3. Kimura Y, Takada T, Kawarada Y, et al. Definitions, pathophysiology, and epidemiology of acute cholangitis and cholecystitis: Tokyo Guidelines. J Hepatobiliary Pancreat Surg 14: 15-26, 2007.

4. Takada T, Kawarada Y, Nimura Y, et al. Background: Tokyo Guidelines for the management of acute cholangitis and cholecystitis. J Hepatobiliary Pancreat Surg 14: 1-10, 2007.

5. Kajiyama G. Natural history of asymptomatic cholelithiasis and management of it. Medicina 29: 278-279, 1992 (in Japanese).

6. Honnma K, Mutou Y. Review of the volume of gallbladder, retraction rate of gallbladder and the dependence of gallstone of the long term bedridden patients with tube feeding. Journal of Japan Biliary Association 13: 285, 1992 Abstract (in Japanese).

7. Sakai K, Nagai H, Haraguchi T, et al. Review of the acute cholecystitis in long term bedridden neuromuscular disease patients. Rinsho Shinkeigaku 49: 1181, 2009 Abstract (in Japanese).

8. Yasuda H, Takada T, Kawarada Y, et al. Unusual cases of acute cholecystitis and cholangitis: Tokyo Guidelines. J Hepatobiliary Pancreat Surg 14: 98-113, 2007.

9. Toepfer M, Folwaczny C, Klauser A, Riepl RL, Müller-Felber W, Pongratz D. Gastrointestinal dysfunction in amyotrophic lateral sclerosis. Amyotroph Lateral Scler Other Motor Neuron Disord 1: 15-19, 1999.

10. Sato K, Namba R, Hayabara T, Kashihara K, Morimoto K. Autonomic nervous disorder in motor neuron disease: a study of advanced stage patients. Intern Med 34: 972-975, 1995.

11. Aneman A, Pontén J, Fändriks L, Eisenhofer G, Friberg P, Biber B. Hemodynamic, sympathetic and angiotensin II responses to PEEP ventilation before and during administration of isoflurane. Acta Anaesthesiol Scand 41: 41-48, 1997.

12. Miller RG, Jackson CE, Kasarskis EJ, et al. Practice parameter update: The care of the patient with amyotrophic lateral sclerosis: Drug, nutritional, and respiratory therapies (an evidence-based review). Neurology 73: 1218-1226, 2009.

\section{(C) 2011 The Japanese Society of Internal Medicine http://www.naika.or.jp/imindex.html}

